\title{
Method of using increasing levels of substitution of the basal diet by test feedstuffs in pig digestibility trials
}

\author{
[Metodologia de uso de níveis crescentes de substituição da ração referência pelo alimento teste em \\ ensaios de digestibilidade com suínos] \\ L.M. Piano ${ }^{1}$, I. Moreira ${ }^{2 *}$, C. Scapinello ${ }^{2}$, P.L.O. Carvalho ${ }^{3}$, J.B. Toledo ${ }^{3}$, G.C. Oliveira ${ }^{1}$ \\ ${ }^{1}$ Zootecnista autônomo \\ ${ }^{2}$ Universidade Estadual do Maringá - Maringá, PR \\ ${ }^{3}$ Aluno de pós-graduação - Universidade Estadual do Maringá - Maringá, PR
}

\begin{abstract}
Two experiments were carried out to study the methodology of using increasing levels of substitution of the basal diet with fibrous test feedstuffs (sticky coffee hull $-\mathrm{SCH}$ ) in digestibility trials with pigs. In Experiment 1, a digestibility trial was conducted using 30 crossbred barrows, allotted in a randomized block design. In Experiment 2, 42 growing and 42 finishing pigs were used, allotted in a completely randomized design, with six diets and seven replicates, with one animal per experimental unit. The six diets consisted of: a control diet, four diets using SCH ME values as obtained in Experiment 1 plus a diet using SCH ME value estimated by linear regression equation for $15 \%$ substitution. The digestibility study indicated that the use of increasing levels of substitution (7, 14, 21 and 28\%) reduced SCH digestibility. ME values, as-fed basis, were $2,456,2,377,2,247$ and $1,945 \mathrm{kcal} / \mathrm{kg}$. The overall results indicate that higher levels of substitution overestimate the energy value and that the method of increasing levels of substitution of the basal diet with feedstuffs test can be used to more accurately estimate the energy values of fibrous feedstuffs for pigs. For growing and finishing pigs respectively, up to $28 \%$ and $15 \%$ of sticky coffee hull can be used without impairing pig performance and economic feasibility.
\end{abstract}

Keywords: carcass traits, fibrous feedstuffs, nutritional value, performance

\section{RESUMO}

Dois experimentos foram realizados para se estudar a metodologia de uso de porcentagens crescentes de substituição da ração referência pelo alimento teste fibroso (casca de café melosa-CCM), em ensaios de digestibilidade com suínos. No Experimento I, foi realizado um ensaio de digestibilidade utilizando 30 machos castrados, distribuídos em delineamento de blocos ao acaso. No Experimento II, foram utilizados 42 suínos na fase de crescimento e 42 suínos na fase de terminação, distribuídos em delineamento inteiramente ao acaso, com seis rações, sete repetições e um animal por unidade experimental. As seis rações foram: uma ração controle, quatro rações usando os valores de energia metabolizável (EM) da CCM obtidos no Experimento I e uma ração com EM da CCM estimada por equação de regressão linear para $15 \%$ de substituição. Os estudos de digestibilidade indicaram que o uso de porcentagens crescentes de substituição - 7, 14, 21 e 28\% - reduziu a digestibilidade da CCM. Os valores de EM, na matéria natural, obtidos para a CCM foram 2.456, 2.377, 2.247 e $1.945 \mathrm{kcal} / \mathrm{kg}$. Os resultados indicam que porcentagens mais elevadas de substituição superestimam o valor energético e que a crescente substituição da ração referência pelo alimento teste pode ser utilizada para estimar, de forma mais precisa, os valores energéticos de alimentos fibrosos para suínos. Para suínos em crescimento e em terminação, pode-se usar, respectivamente, até $28 \%$ e $15 \%$ de casca de café melosa sem prejudicar o desempenho e a viabilidade econômica.

Palavras-chave: alimento fibroso, característica de carcaça, desempenho, valor nutricional

Recebido em 4 de março de 2011

Aceito em 20 de abril de 2012

*Autor para correspondência (corresponding author)

E-mail: imoreira@uem.br 


\section{INTRODUCTION}

Feeding represents the largest share of production costs in swine breeding. Consequently, there is great interest in the use of alternative ingredients, such as fibers, in order to achieve good productive performance while reducing costs. Dietary fiber is considered an alternative source of energy in pigs diets (Gomes et al., 2007). Although it reduces the digestibility of most nutritional components, it can be included in corn-based diets, resulting in adequate weight gain and satisfactory yield in lean meat, leading to improvements in carcass quality.

Traditionally, digestibility trials with pigs use only a single level of substitution of a test feedstuff for the basal diet (Sakomura and Rostagno, 2007). According to Nascimento et al. (2005), one factor that can influence the variation found in nutrient digestibility values is precisely the rate of substitution of the basal diet by the test feedstuff. To Adeola (2001), at least two levels of substitution of a basal diet component by a given test feedstuff should be used to estimate digestibility. This could be done by applying a digestibility regression of the components substituted at the different levels and extrapolating to $100 \%$ substitution. There is a risk in extrapolating the levels tested outside the substitution interval, and the errors associated are inversely related to the level of basal diet substituted by the test feedstuff. One solution would be to use several different levels of basal diet substitution and analyze the results using simple or multiple regression to estimate the parameters of desired energy contents (Villamide et al., 1998).

In digestibility studies, the method of using increasing levels of substitution of the basal diet by a test feedstuff consists of using the test feedstuff mixed in ever-higher levels to a basal diet calculated according to the requirements established for the animal species in question (Villamide, 1996). It is expected that this method will improve the energy values estimates of diets.

This work aimed to evaluate the method of substitution increasing levels of the basal diet by a test feedstuff on the nutrient digestibility and energy value of sticky coffee hull (SCH) (fibrous feedstuff) for growing-finishing pigs, as well as validate the metabolizable energy values obtained from a performance experiment.

\section{MATERIAL AND METHODS}

The sticky coffee hulls (chosen as the fibrous feedstuff) were ground in a hammer mill using a $4 \mathrm{~mm}$ screen size. The composition of $\mathrm{SCH}$ was as follows: $9.3 \%$ crude protein $(\mathrm{CP}) ; 3,734 \mathrm{kcal}$ of gross energy $/ \mathrm{kg} ; 18.86 \%$ crude fiber $(\mathrm{CF})$; $31.5 \%$ neutral detergent fiber (NDF); $25.4 \%$ acid detergent fiber (ADF); $0.31 \%$ calcium (Ca); $0.07 \%$ total phosphorus (tP); and a geometric mean diameter (GMD) of $1,533 \mathrm{~mm}$. The analyses of dry matter, organic matter, ash, CP, $\mathrm{CF}, \mathrm{NDF}, \mathrm{ADF}, \mathrm{Ca}$ and $\mathrm{tP}$ were performed according to the methods described by Silva and Queiroz (2002). Particle size analyses were performed according to the method proposed by Zanotto and Bellaver (1996).

In Experiment 1 a digestibility trial was conducted using 30 commercial-line castrated male pigs, with $72.48 \pm 7.16 \mathrm{~kg}$ initial body weight. The animals were individually penned in metabolism cages similar to those described by Pekas (1968) in a partially climate-controlled facility. Using the method of substitution increasing levels of the basal diet by a test feedstuff, according to Villamide (1996), four different diets were formulated with four levels of substitution $(7 \%, 14 \%, 21 \%$ and $28 \%)$ of the basal diet (BD). SCH substituted, based on dry matter. The $\mathrm{BD}$, based on corn and soybean meal, was calculated to meet the requirements indicated by the NRC (1998). In total, five diets were used: $\mathrm{BD} ; \mathrm{BD}(93 \%)+\mathrm{SCH}(7 \%) ; \mathrm{BD}$ $(86 \%)+\mathrm{SCH}(14 \%) ; \mathrm{BD}(79 \%)+\mathrm{SCH}(21 \%)$ and $\mathrm{BD}(72 \%)+\mathrm{SCH}(28 \%)$

Collection periods lasting 15 days, being 10 days for acclimation and five days for total feces and urine collection. The experimental design consisted of randomized blocks, with four diets, six replicates, and the experimental unit consisting of one pig. Feedings were at $8 \mathrm{AM}$ and at 4PM. To mark the beginning and end of each period of total feces collection, $\mathrm{Fe}_{3} \mathrm{O}_{2} 2 \%$ was used as a fecal marker. Samples were collected once a day, conditioned in plastic bags and stored at $-18^{\circ} \mathrm{C}$.

The study obtained the digestibility coefficients (one for each level of substitution) of dry matter 
(DCDM), gross energy (DCGE), organic matter (DCOM), crude protein (DCCP), neutral detergent fiber (DCNDF), acid detergent fiber (DCADF), crude fiber (DCCF) and metabolization coefficient of gross energy (MCGE) of SCH, according to Moreira et al. (1994). Next, the values were calculated for DDM, DE, ME, DOM, DCP, DNDF, DADF and DCF, according to Matterson et al. (1965). The remaining experimental procedures were performed according to Fialho et al. (1979).

The digestibility coefficients were submitted to polynomial regression analysis, as suggested by Villamide (1996), using SAEG software (Sistema..., 1997), according to the following statistical model: $\mathrm{Yijk}=\mu+\mathrm{b} 1(\mathrm{Ni}-\mathrm{N})+\mathrm{b} 2(\mathrm{Ni}-$ $\mathrm{N})+\mathrm{Bj}+\mathrm{eijk}$, in which: Yijk= observed value of the studied variables, relative to each individual $j$, receiving level $i$ of feedstuff substitution, $\mu=$ overall constant; $b 1=$ linear regression coefficient of the level of substitution on variable $Y$; b2 $=$ quadratic regression coefficient of the level of substitution on variable $Y ; \mathrm{Ni}=$ levels of substitution in the diets, with $i=7,14$, 21 and $28 \% ; \mathrm{N}=$ mean levels of substitution in the diets; $\mathrm{Bj}=$ block effect on variable $Y$; eijk= random error associated with each observation.

Experiment 2 was a performance assay using 42 crossbred, commercial-line growing pigs with $30.27 \pm 1.95 \mathrm{~kg}$ initial body weight and $60.00 \pm 4.49 \mathrm{~kg}$ final weight, and 42 finishing pigs with $60.02 \pm 4.10 \mathrm{~kg}$ initial body weight and $89.76 \pm 8.89 \mathrm{~kg}$ final weight.

Average minimum temperatures during the experimental periods were $17.9 \pm 3.7^{\circ} \mathrm{C}$ and $21.5 \pm 4.6^{\circ} \mathrm{C}$, and maximum temperatures were $30.0 \pm 5.5^{\circ} \mathrm{C}$ and $30.2 \pm 5.2^{\circ} \mathrm{C}$, respectively. Relative air humidity averages during growing and finishing stages stood at $38.5 \pm 16,0 \%$ and $71.3 \pm 15.2 \%$ in the morning and $40.2 \pm 16,0 \%$ and $64.8 \pm 17.6 \%$ in the afternoon, respectively.

Treatments consisted of six diets (Tables 1 and $2)$ : one control diet, four diets formulated using the ME values of SCH $(2,456,2,377,2,247$ and $1,945 \mathrm{kcal} \mathrm{ME} / \mathrm{kg}$ ), obtained with the different levels of substitution $(7,14,21$ and $28 \%)$ of BD by the test feedstuff ( $\mathrm{SCH})$, respectively; and one diet using a ME value of $2,316 \mathrm{kcal} \mathrm{ME} / \mathrm{kg}$, estimated for $15 \%$ substitution of $\mathrm{SCH}$. In order to reach the estimate value of $2,316 \mathrm{kcal} \mathrm{ME} / \mathrm{kg}$, initially a linear equation was obtained through a regression of ME values, in function of the levels of substitution. Once the equation was obtained, $\mathrm{ME}_{15 \%}=2,672-23,757 \mathrm{X}$, the value of ME was estimated for $\mathrm{X}=15 \%$. Likewise, $\mathrm{ME}$ was estimated for $100 \%$ substitution, according to Villamide (1996) and Adeola (2001), which resulted in a non-real value $(296.3 \mathrm{kcal} \mathrm{ME} / \mathrm{kg}$ ); therefore, no diet was formulated using that value.

Corn and soybean meal-based diets were formulated to meet requirements recommended by the NRC (Nutrient..., 1998) for growing pigs (30-60 kg) (Tab. 1) and finishing pigs (60-90kg) (Tab. 2). The level of SCH was set at $15 \%$, as this level was indicated as best in previous study (Poveda-Parra et al., 2008). For diet formulation, the chemical and energy composition of $\mathrm{SCH}$ was used, obtained during the digestibility assay. For corn and soybean meal, the values of $\mathrm{CP}$, phosphorus and calcium were determined, while ME levels were indicated by Rostagno et al. (2005).

The pigs were allotted in a random blocks experimental design, with six diets, and experimental units consisting of one pig per pen.

At the end of the growing and finishing phases, backfat thickness and loin depth at the P2 position were measured using a Sono-Grader device $\left(\mathrm{RENCO}^{\circledR}\right)$. Likely, 36 finishing pigs were slaughtered and carcasses were evaluated, according to the Brazilian Method of Carcass Classification (Associação..., 1973). For a qualitative carcass evaluation, samples were taken from Longissimus dorsi muscle in the area of the $8^{\text {th }}$ and $10^{\text {th }}$ vertebrae for later measurements of intramuscular fat (marbling) and water loss from dripping, according to Bridi and Silva (2006). Longissimus dorsi and fat areas were determined using a digital table (Camara $e t$ al., 1996). 
Table 1. Composition of diets formulated with different values of metabolizable energy from sticky coffee hull - growing pigs

\begin{tabular}{|c|c|c|c|c|c|c|}
\hline \multirow[t]{2}{*}{ Item } & \multicolumn{6}{|c|}{$\begin{array}{l}\text { Levels of substitution of basal diet to estimate } \\
\text { metabolizable energy of sticky coffee hull }{ }^{1}(\%)\end{array}$} \\
\hline & $\mathrm{CD}$ & 7 & 14 & 21 & 28 & 15 \\
\hline Corn & 73.43 & 57.78 & 57.46 & 56.92 & 55.66 & 57.20 \\
\hline Sticky coffee hull & 0.00 & 15.00 & 15.00 & 15.00 & 15.00 & 15.00 \\
\hline Soybean meal & 18.63 & 22.63 & 22.71 & 22.85 & 23.19 & 22.78 \\
\hline Soybean oil & 0.41 & 2.15 & 2.40 & 2.80 & 3.73 & 2.59 \\
\hline Limestone & 0.70 & 0.43 & 0.43 & 0.42 & 0.42 & 0.42 \\
\hline Dicalcium phosphate & 0.85 & 1.13 & 1.13 & 1.13 & 1.14 & 1.13 \\
\hline Salt & 0.40 & 0.40 & 0.40 & 0.40 & 0.40 & 0.40 \\
\hline Mineral-vitamin premix ${ }^{2}$ & 0.30 & 0.30 & 0.30 & 0.30 & 0.30 & 0.30 \\
\hline Growth promoter ${ }^{3}$ & 0.05 & 0.05 & 0.05 & 0.05 & 0.05 & 0.05 \\
\hline L-Lysine HCL & 0.23 & 0.13 & 0.13 & 0.13 & 0.12 & 0.13 \\
\hline Weath bran & 5.00 & 0.00 & 0.00 & 0.00 & 0.00 & 0.00 \\
\hline \multicolumn{7}{|l|}{ Calculated values $^{4}$} \\
\hline Metabolizable energy, $\mathrm{kcal} / \mathrm{kg}$ & 3,230 & 3,230 & 3,230 & 3,230 & 3,230 & 3,230 \\
\hline Protein, $\%$ & 17.00 & 17.00 & 17.00 & 17.00 & 17.00 & 17.00 \\
\hline Lysine, \% & 0.91 & 0.91 & 0.91 & 0.91 & 0.91 & 0.91 \\
\hline Calcium, \% & 0.55 & 0.55 & 0.55 & 0.55 & 0.55 & 0.55 \\
\hline Total phosporus, $\%$ & 0.480 & 0.480 & 0.480 & 0.480 & 0.480 & 0.480 \\
\hline Neutral detergent fiber, $\%$ & 12.91 & 15.70 & 15.70 & 15.70 & 15.70 & 15.70 \\
\hline Acid detergent fiber, $\%$ & 5.26 & 8.28 & 8.28 & 8.28 & 8.28 & 8.28 \\
\hline Crude fiber, $\%$ & 3.28 & 5.62 & 5.62 & 5.62 & 5.62 & 5.62 \\
\hline Feed cost, $\mathrm{R} \$ / \mathrm{kg}$ & 0.58 & 0.65 & 0.65 & 0.66 & 0.68 & 0.66 \\
\hline
\end{tabular}

${ }^{1}$ The values of metabolizable energy of sticky coffee hull (SCH) used to calculate the diets were 2,456, 2,377, 2,247, 1,945 and 2,316 , respectively to $7,14,21,28$ e $15 \%$ of inclusion of SCH substituting basal diet. The level of $15 \%$ was estimated by regression. CD: control diet. ${ }^{2}$ Vitamin and mineral premix for pigs in the growing. ${ }^{3}$ Lincomicyn $30 \% .{ }^{4}$ Calculate based on Rostagno et al. (2005).

Table 2. Composition of diets formulated with different values of metabolizable energy from sticky coffee hull - finishing pigs

\begin{tabular}{|c|c|c|c|c|c|c|}
\hline \multirow[t]{2}{*}{ Item } & \multicolumn{6}{|c|}{$\begin{array}{l}\text { Levels of substitution of basal diet to estimate } \\
\text { metabolizable energy of sticky coffee hull }{ }^{1}(\%)\end{array}$} \\
\hline & $\mathrm{CD}$ & 7 & 14 & 21 & 28 & 15 \\
\hline Corn & 81.45 & 65.83 & 65.59 & 64.96 & 63.71 & 65.25 \\
\hline Sticky coffee hull & 0.00 & 15.00 & 15.00 & 15.00 & 15.00 & 15.00 \\
\hline Soybean meal & 11.11 & 15.1 & 15.1 & 15.33 & 15.66 & 15.25 \\
\hline Soybean oil & 0.00 & 1.74 & 1.98 & 2.38 & 3.31 & 2.17 \\
\hline Limestone & 0.69 & 0.41 & 0.41 & 0.41 & 0.40 & 0.41 \\
\hline Dicalcium phosphate & 0.70 & 0.97 & 0.97 & 0.97 & 0.98 & 0.97 \\
\hline Salt & 0.40 & 0.40 & 0.40 & 0.40 & 0.40 & 0.40 \\
\hline Mineral-vitamin premix ${ }^{2}$ & 0.30 & 0.30 & 0.30 & 0.30 & 0.30 & 0.30 \\
\hline Growth promoter ${ }^{3}$ & 0.05 & 0.05 & 0.05 & 0.05 & 0.05 & 0.05 \\
\hline L-Lysine HCL & 0.30 & 0.20 & 0.20 & 0.20 & 0.20 & 0.20 \\
\hline Weath bran & 5.00 & 0.00 & 0.00 & 0.00 & 0.00 & 0.00 \\
\hline \multicolumn{7}{|l|}{ Calculate values $^{4}$} \\
\hline Metabolizable energy, $\mathrm{Kcal} / \mathrm{kg}$ & 3,197 & 3,197 & 3,197 & 3,197 & 3,197 & 3,197 \\
\hline Protein, $\%$ & 13.85 & 13.85 & 13.85 & 13.85 & 13.85 & 13.85 \\
\hline Lysine, \% & 0.77 & 0.77 & 0.77 & 0.77 & 0.77 & 0.77 \\
\hline Calcium, \% & 0.49 & 0.49 & 0.49 & 0.49 & 0.49 & 0.49 \\
\hline Total phosporus, $\%$ & 0.43 & 0.43 & 0.43 & 0.43 & 0.43 & 0.43 \\
\hline Neutral detergent fiber, $\%$ & 13.02 & 15.80 & 15.80 & 15.80 & 15.80 & 15.80 \\
\hline Acid detergent fiber, $\%$ & 5.74 & 8.69 & 8.69 & 8.69 & 8.69 & 8.69 \\
\hline Crude fiber, $\%$ & 3.23 & 5.57 & 5.57 & 5.57 & 5.57 & 5.57 \\
\hline Feed cost, $\mathrm{R} \$ / \mathrm{kg}$ & 0.59 & 0.66 & 0.66 & 0.67 & 0.69 & 0.67 \\
\hline
\end{tabular}


In order to study the economic viability of each experiment diet, diet cost (DC) was calculated along with feed cost per $\mathrm{kg}$ of body weight (ADI), according to Bellaver et al. (1985). The economic efficiency index (EEI) and cost index (CI) were calculated as well, according to the methodology proposed by Gomes et al. (1991). The supplies prices were obtained at local market and used to calculate the costs of the experimental diets: corn (grain), R\$ $0.36 / \mathrm{kg}$; soybean meal, R\$ $0.92 / \mathrm{kg}$; soybean oil $\mathrm{R} \$$ $2.14 / \mathrm{kg}$; and sticky coffee hull, $\mathrm{R} \$ 0.50 / \mathrm{kg}$.

The results of the performance, carcass traits and feed costs were submitted to an analysis of variance. NCK test was applied when necessary the statistical analyses were done using the SAEG statistics software (Sistema..., 1997).

\section{RESULTS AND DISCUSSION}

For the digestibility assay, the sticky coffee hulls were ground into $4 \mathrm{~mm}$ particle sizes, as a study by Poveda-Parra et al. (2008) demonstrated that sticky coffee hulls ground into that size present a better digestibility coefficient than hulls ground in a $2.5 \mathrm{~mm}$ screen sieve. The particle sizes of the tested feeds were 533, 606, 628 and 656, respectively, for levels 7, 14, 21 and $28 \%$ of hulls in the diets.

The digestibility coefficients (Table 3 ) for sticky coffee hulls were lower than those obtained by Poveda-Parra et al. (2008) and Ferreira et al. (1997) for DE $(2,498$ and $2,843 \mathrm{kcal} / \mathrm{kg}$, respectively) and DCCP (45.7 and 65.5\%, respectively). Similarly, the values found are lower than those observed by Oliveira et al. (2002) and Ferreira et al. (1997) for DDM (65.6 and $61.0 \%$, respectively) and $\mathrm{ME}(2,684$ and $2,694 \mathrm{kcal} / \mathrm{kg}$, respectively). In general, the coefficients of variation were high, which made more difficult the detection of differences $(\mathrm{P} \leq 0.05)$ among the digestibility coefficients.

Fiber is one of the factors that contribute to the reduction in the digestibility of ingredients used in pig diets (Noblet e Perez, 1993). There may be decrease in dry matter digestibility result of the partial substitution of a highly digestible carbohydrate source (corn starch) by another less digestible source, rich in non-starch polysaccharides (NSP), with lower fermentation or through an increase in intestinal transit, leading to a reduction in the fermentation of structural carbohydrates (Gomes et al., 2007).

Table 3. Digestibility coefficients and digestible nutrients of sticky coffee hull - growing-finishing pigs

\begin{tabular}{|c|c|c|c|c|c|c|c|c|c|}
\hline \multirow{2}{*}{$\begin{array}{l}\text { Digestibility coeficients }{ }^{1} \text {, } \\
\end{array}$} & \multicolumn{8}{|c|}{ Levels of sticky coffee hull $^{2}$} & \multirow[b]{2}{*}{$\operatorname{Reg}^{3}$} \\
\hline & \multicolumn{2}{|c|}{7} & \multicolumn{2}{|c|}{14} & \multicolumn{2}{|c|}{21} & \multicolumn{2}{|c|}{28} & \\
\hline DC of Dry matter & \multicolumn{2}{|c|}{74.46} & \multicolumn{2}{|c|}{74.73} & \multicolumn{2}{|c|}{73.10} & \multicolumn{2}{|c|}{66.68} & NS \\
\hline DC of Gross energy & \multicolumn{2}{|c|}{67.91} & \multicolumn{2}{|c|}{66.84} & \multicolumn{2}{|c|}{63.34} & \multicolumn{2}{|c|}{57.35} & NS \\
\hline MC of Gross energy & \multicolumn{2}{|c|}{65.77} & \multicolumn{2}{|c|}{63.68} & \multicolumn{2}{|c|}{60.18} & \multicolumn{2}{|c|}{52.10} & NS \\
\hline $\mathrm{DC}$ of OM & \multicolumn{2}{|c|}{58.96} & \multicolumn{2}{|c|}{64.46} & \multicolumn{2}{|c|}{74.26} & \multicolumn{2}{|c|}{67.69} & NS \\
\hline DC of Crude protein & \multicolumn{2}{|c|}{38.87} & \multicolumn{2}{|c|}{41.91} & \multicolumn{2}{|c|}{41.64} & \multicolumn{2}{|c|}{31.76} & NS \\
\hline DC of NDF & \multicolumn{2}{|c|}{16.50} & \multicolumn{2}{|c|}{48.81} & \multicolumn{2}{|c|}{59.90} & \multicolumn{2}{|c|}{37.51} & Q:0.000 \\
\hline $\mathrm{DC}$ of $\mathrm{ADF}$ & \multicolumn{2}{|c|}{13.98} & \multicolumn{2}{|c|}{19.85} & \multicolumn{2}{|c|}{55.06} & \multicolumn{2}{|c|}{61.35} & $\mathrm{~L}: 0.000$ \\
\hline DC of Crude fiber & & & & & & & & & Q:0.001 \\
\hline Digestible nutrients $^{4}$ & $\mathrm{DM}^{5}$ & $\mathrm{NM}^{6}$ & $\mathrm{DM}^{5}$ & $\mathrm{NM}^{6}$ & $\mathrm{DM}^{5}$ & $\mathrm{NM}^{6}$ & $\mathrm{DM}^{5}$ & $\mathrm{NM}^{6}$ & \\
\hline DDM, $\%$ & 66.85 & 60.03 & 67.10 & 60.25 & 65.64 & 58.94 & 59.87 & 53.76 & - \\
\hline $\mathrm{DE}, \mathrm{kcal} / \mathrm{kg}$ & 2,824 & 2,535 & 2,779 & 2,496 & 2,634 & 2,365 & 2,385 & 2,141 & - \\
\hline $\mathrm{ME}, \mathrm{kcal} / \mathrm{Kg}$ & 2,735 & 2,456 & 2,648 & 2,377 & 2,502 & 2,247 & 2,166 & 1,945 & - \\
\hline DOM, \% & 54.87 & 49.26 & 59.99 & 53.86 & 69.11 & 62.05 & 63.00 & 56.57 & - \\
\hline $\mathrm{DCP}, \%$ & 4.05 & 3.63 & 4.36 & 3.92 & 4.34 & 3.98 & 3.31 & 2.97 & - \\
\hline DNDF, $\%$ & 5.79 & 5.20 & 17.13 & 15.38 & 21.03 & 18.88 & 13.17 & 11.82 & - \\
\hline DADF, $\%$ & 3.96 & 3.55 & 5.62 & 5.05 & 15.59 & 14.00 & 17.37 & 15.60 & - \\
\hline DCF, $\%$ & 7.38 & 6.63 & 10.42 & 9.35 & 10.02 & 9.00 & 7.18 & 6.45 & - \\
\hline
\end{tabular}

${ }^{1-} \mathrm{DC}=$ Digestibility coefficients, $\mathrm{MC}=$ Metabolization coefficient, $\mathrm{OM}=$ Organic matter, NDF = Neutral detergent fiber, ADF = Acid detergent fiber; ${ }^{2-}$ Represents the levels of substitution of basal diet for food test (sticky coffee hull); ${ }^{3-}$ Regression: NS $=$ not significant, $\mathrm{L}=$ linear effect, $\mathrm{Q}=$ quadratic effect, $\mathrm{DCNDF}=-46,4167+10,8099 \mathrm{X}-0,278166 \mathrm{X}^{2}, \mathrm{CDFDA}=-5,80232+2,52783 \mathrm{X}$ e $\mathrm{DCCF}=7,63523+4,96461 \mathrm{X}-0,14378 \mathrm{X}^{2} ;{ }^{4-}$ Digestible dry matter (DDM); Digestible energy (DE); Metabolizable energy (ME); Digestible organic matter (DOM); Digestible crude protein (DCP); Digestible neutral detergent fiber (DNDF); Digestible acid detergent fiber (DADF) and Digestible crude fiber (DCF); ${ }^{5-}$ Dry matter; ${ }^{6-}$ Natural matter 
The digestible coefficients (DC) and metabolizable coefficients (MC) of gross energy were not influenced $(\mathrm{P}>0.05)$ by the levels of substitution, but for Pond et al. (1988) found a reduction in the digestibility of energy in diets with high fiber inclusion. According to Kempen (2001) for each $1 \%$ of fiber added to the diet of pigs, energy digestibility also falls by at least $1 \%$.

The DCs of NDF and CF showed a quadratic response $(\mathrm{P} \leq 0.05)$ to the levels of substitution, featuring higher estimated DC $(58.6 \%$ and $50.5 \%$ ) at the levels of substitution of $19.43 \%$ and $17.25 \%$ of basal diet by the test feedstuff $(\mathrm{SCH})$. On the other hand, as the level of substitution increased, there was a linear increase $(\mathrm{P} \leq 0.05)$ in the DC of ADF. Applying the mean value $(18.3 \%)$ among the best levels obtained for DCNDF and DCCF, the value of $40.6 \%$ was obtained for the DC of ADF. Compared with the results obtained by Poveda-Parra et al. (2008), who found values of $54.6 \%$ for DCNDF, $50.1 \%$ for DCCF, and $50.3 \%$ for DCADF, the results in this experiment (Table 3) were lower for NDF, similar for $\mathrm{CF}$, and higher for $\mathrm{ADF}$.

Traditionally in pig digestibility trials, only one level of substitution of the basal diet by the test feedstuff is used, from 25\% to $30 \%$ (Sakomura and Rostagno, 2007), but as cited by Villamide (1996) and Adeola (2001), it is important to use more than one level of substitution.

In the performance experiment, when $\mathrm{SCH}$ was included at a fixed level of $15 \%$ in growing diets and the different $\mathrm{ME}$ values obtained in the digestibility assay were used, a similar performance was obtained (Table 4). This suggests that the energy value (ME) of fibrous feedstuffs $(\mathrm{SCH})$ indeed varies according to the level of substitution of the basal diet by the test feedstuff $(\mathrm{SCH})$.

Table 4. Performance ${ }^{1}$ and carcass traits ${ }^{2}$ of grow-finishing pigs fed on diets formulated with different metabolizable energy values of sticky coffee hulls

Levels of substitution of basal diet used in digestibility trials to estimate metabolizable energy of sticky coffee hull $^{3}(\%)$

\begin{tabular}{|c|c|c|c|c|c|c|c|c|}
\hline \multirow{2}{*}{ Item } & \multirow[b]{2}{*}{$\mathrm{CD}^{4}$} & & \multirow[b]{2}{*}{ Mean } & \multirow[b]{2}{*}{$\mathrm{SE}^{5}$} \\
\hline & & 7 & 14 & 21 & 28 & 15 & & \\
\hline \multicolumn{9}{|c|}{ Growing } \\
\hline DFI, kg & 1.89 & 1.75 & 1.87 & 1.95 & 1.73 & 1.92 & 1.85 & \pm 0.03 \\
\hline DWG, kg & 0.753 & 0.713 & 0.752 & 0.818 & 0.716 & 0.776 & 0.755 & \pm 0.01 \\
\hline FGR & 2.49 & 2.48 & 2.51 & 2.44 & 2.48 & 2.50 & 2.48 & \pm 0.02 \\
\hline $\mathrm{BT}-\mathrm{P} 2, \mathrm{~mm}$ & 9.00 & 7.00 & 7.29 & 7.86 & 7.29 & 8.00 & 7.74 & \pm 0.24 \\
\hline $\mathrm{LD}, \mathrm{mm}$ & 45.71 & 36.71 & 41.86 & 40.29 & 36.43 & 43.00 & 40.67 & \pm 1.01 \\
\hline \multicolumn{9}{|c|}{ Finishing } \\
\hline DFI, kg & 2.44 & 2.26 & 2.35 & 1.99 & 1.97 & 2.17 & 2.20 & \pm 0.05 \\
\hline DWG, $\mathrm{kg}$ & $0.831 \mathrm{a}$ & $0.678 \mathrm{ab}$ & $0.723 \mathrm{ab}$ & $0.576 \mathrm{~b}$ & $0.605 b$ & $0.645 \mathrm{ab}$ & 0.676 & \pm 0.02 \\
\hline FGR & 2.94 & 3.37 & 3.39 & 3.63 & 3.34 & 3.45 & 3.36 & \pm 0.07 \\
\hline $\mathrm{BT}-\mathrm{P} 2, \mathrm{~mm}$ & 11.57 & 10.00 & 12.29 & 10.51 & 8.71 & 10.00 & 10.51 & \pm 0.36 \\
\hline $\mathrm{LD}, \mathrm{mm}$ & 56.57 & 50.43 & 49.14 & 52.12 & 51.86 & 52.43 & 52.09 & \pm 1.25 \\
\hline
\end{tabular}

${ }^{\mathrm{T}} \mathrm{DFI}=$ Daily feed intake, $\mathrm{DWG}=$ Daily weight gain, FGR $=$ Feed to gain ratio ${ }^{2} \mathrm{BT}-\mathrm{P} 2=$ Backfat thickness in position $2, \mathrm{LD}=$ Loin depth; ${ }^{3}$ The values of metabolizable energy of sticky coffee hull (SCH) used to calculate the diets were 2,456, 2,377, 2,247, 1,945 and 2,316 , respectively to $7,14,21,28$ e $15 \%$ of inclusion of SCH substituting basal diet. The level of $15 \%$ was estimated by regression; ${ }^{4}$ Control diet $(\mathrm{CD}) ;{ }^{5}$ Standard error.

This response in performance: daily feed intake (DFI), daily weight gain (DWG) and feed-togain ratio (FGR); and carcass (backfat thickness and loin depth), during the growing phase, indicates that the energy values (ME) estimated during the digestibility trial, using different levels of substitution of the basal diet by $\mathrm{SCH}$, represent the true energy values of $\mathrm{SCH}$, for that phase (growing).

For the finishing phase, the DWG (Table 4) was lower $(\mathrm{P} \leq 0.05)$ for levels $21 \%$ and $28 \%$ compared to the control diet, which may indicate energy deficiency in those diets. If energy 
deficiency occurred, it means the energy value of SCH obtained with $21 \%$ and $28 \%$ of BD substitution has been overestimated.

These responses suggest that, for fibrous feedstuffs, the addition of high levels of substitution of BD by the test feedstuff (fibrous) for finishing pigs may lead to an overestimated ME value. Thus, increasing levels of substitution can be used to determine which level provides the best energy value of the feedstuff tested (Villamide, 1996).

Some carcass traits (Table 5) such as hot carcass weight, cold carcass weight, ham weight and backfat thickness, support the performance responses that suggest overestimated $\mathrm{SCH}$ energy values for the $21 \%$ and $28 \%$ levels, with emphasis on the higher level of substitution. The $28 \%$ diet, which supposedly provided lower energy levels than the control diet, showed smaller carcass and with less fat, which again supports the possibility that the ME value for $\mathrm{SCH}$ was overestimated for this level of substitution in the performance experiment. In regard to the above mentioned results, for Gomes et al. (2007) the reduction in body fat and increase in muscle mass result in improved carcass quality, although it is common for these traits to be associated with lower weight gain in pigs fed with fibrous diets.

Table 5. Carcass traits of pigs fed on diets with different values of metabolizable energy of sticky coffee hull

\begin{tabular}{|c|c|c|c|c|c|c|c|c|}
\hline \multirow[b]{2}{*}{ Item $^{2}$} & \multirow[b]{2}{*}{$\mathrm{CD}^{3}$} & \multicolumn{5}{|c|}{$\begin{array}{l}\text { Levels of substitution of basal diet used in digestibility } \\
\text { trials to estimate metabolizable energy of sticky coffee } \\
\text { hull }{ }^{1}(\%)\end{array}$} & \multirow[b]{2}{*}{ Mean } & \multirow[b]{2}{*}{$\mathrm{SE}^{4}$} \\
\hline & & 7 & 14 & 21 & 28 & 15 & & \\
\hline \multicolumn{9}{|c|}{ Carcass traits } \\
\hline$\overline{\mathrm{SW}}, \mathrm{kg}$ & 93.48 & 86.07 & 87.48 & 82.87 & 80.63 & 84.57 & 85.97 & \pm 1.24 \\
\hline $\mathrm{HCW}, \mathrm{kg}$ & 77.74 & 68.80 & 70.78 & 67.83 & 65.04 & 68.58 & 69.85 & \pm 1.01 \\
\hline YHC, \% & 83.09 & 80.00 & 80.88 & 81.83 & 80.59 & 81.13 & 81.20 & \pm 0.28 \\
\hline $\mathrm{CCW}, \mathrm{kg}$ & $75.73 a$ & $66.96 \mathrm{~b}$ & $68.84 \mathrm{ab}$ & $65.79 \mathrm{ab}$ & $63.11 \mathrm{~b}$ & $66.73 \mathrm{ab}$ & 67.92 & \pm 1.06 \\
\hline YCC, $\%$ & 80.95 & 77.85 & 78.66 & 79.38 & 78.19 & 78.91 & 78.94 & \pm 0.25 \\
\hline LI, \% & 2.56 & 2.67 & 2.75 & 3.00 & 2.99 & 2.73 & 2.77 & \pm 0.10 \\
\hline $\mathrm{HW}, \mathrm{kg}$ & $12.18 \mathrm{~b}$ & $10.92 \mathrm{a}$ & $11.23 b$ & $10.78 b$ & $10.03 b$ & $10.87 b$ & 10.99 & \pm 0.15 \\
\hline $\mathrm{IH}, \mathrm{kg}$ & $32.25 \mathrm{c}$ & $32.61 \mathrm{a}$ & $32.63 b c$ & $32.75 b c$ & $32.05 \mathrm{~b}$ & $32.58 \mathrm{bc}$ & 32.40 & \pm 0.20 \\
\hline $\mathrm{BT}, \mathrm{cm}$ & 2.84 & 2.50 & 2.58 & 2.24 & 2.04 & 2.29 & 2.42 & \pm 0.07 \\
\hline $\mathrm{CL}, \mathrm{cm}$ & 91.75 & 90.14 & 92.35 & 89.62 & 90.78 & 91.77 & 91.10 & \pm 0.49 \\
\hline $\mathrm{EAL}, \mathrm{cm}^{2}$ & 49.55 & 39.37 & 38.55 & 40.83 & 38.45 & 41.06 & 41.30 & \pm 1.07 \\
\hline LM, & 66.13 & 55.85 & 55.92 & 57.40 & 55.07 & 57.81 & 58.03 & \pm 1.14 \\
\hline PLM, & 85.05 & 81.42 & 79.05 & 84.64 & 84.83 & 84.15 & 83.13 & \pm 1.24 \\
\hline DL, $\%$ & 3.79 & 3.16 & 3.31 & 3.33 & 4.22 & 2.91 & 3.47 & \pm 0.27 \\
\hline MAR & 2.50 & 1.75 & 1.83 & 1.80 & 1.83 & 2.00 & 1.97 & \pm 0.11 \\
\hline $\mathrm{COL}$ & $2.25 \mathrm{~b}$ & $2.17 \mathrm{~b}$ & $2.33 \mathrm{a}$ & $2.23 \mathrm{a}$ & $2.17 \mathrm{a}$ & $2.17 \mathrm{a}$ & 2.24 & \pm 0.07 \\
\hline FIRM & $2.42 \mathrm{~b}$ & $2.58 b$ & $2.75 a$ & $2.69 a$ & $2.75 \mathrm{a}$ & $2.67 \mathrm{a}$ & 2.65 & \pm 0.04 \\
\hline
\end{tabular}

${ }^{1}$ The values of metabolizable energy of sticky coffee hull $(\mathrm{SCH})$ used to calculate the diets were 2,456, 2,377, 2,247, 1,945 and 2,316 , respectively to $7,14,21,28$ e $15 \%$ of inclusion of SCH substituting basal diet. The level of $15 \%$ was estimated by regression. ${ }^{2} \mathrm{SW}=$ Slaughter weight, $\mathrm{HCW}=$ hot carcass weight, $\mathrm{YHC}=$ yeld hot carcass, $\mathrm{CCW}=$ cold carcass weight, $\mathrm{YCC}=$ yeld cold carcass, $\mathrm{LI}=$ loss of income, $\mathrm{HW}=$ ham weight, $\mathrm{IH}=$ income ham, $\mathrm{BT}=$ backfat thickness, $\mathrm{CL}=$ carcass lenght, $\mathrm{ELA}=$ eye loin area, $\mathrm{LM}=$ lean meat in the carcass, PLM = percentage of lean meat in the carcass, DL $=$ drip loss, MAR = marbling of the longíssimus dorsi, $\mathrm{COL}=$ color and FIRM $=$ firmness of meat. ${ }^{3}$ Control diet $(\mathrm{CD}) .{ }^{4}$ Standard error. 
The results obtained in this study are similar to those obtained by Oliveira et al. (2002) and Quadros (2007), using fibrous feedstuffs such as sticky coffee hulls and soybean hulls, respectively, who all observed a reduction in fat percentage and backfat thickness in the diets that contained fiber. Gomes et al. (2006) highlight that some factors may interfere in carcass quality results, such as the quality of the fiber used, fermentation rate, and fiber concentration in the diet.

The economic analysis (Table 6) indicated that for growing animals, the increasing levels of substitution did not influence $(\mathrm{P}>0.05)$ diet costs (DC), whereas it indicated an increase $(\mathrm{P} \leq 0.05)$ for the higher levels of substitution of the basal diet by the test feedstuff in finishing pigs. The results reflect the weaker performance (Table 4), particularly of DWG, during the finishing phase.

Both the SCH energy values found in the digestibility trial and the results of the validation of these values in the animal performance experiment indicate that the method of using increasing levels of substitution of the basal diet by the test feedstuff can be used to better estimate the energy values of feedstuffs for pigs.

Table 6. Economic analysis of growing-finishing pigs fed on diets with different values of metabolizable energy of sticky coffee hull

\begin{tabular}{|c|c|c|c|c|c|c|c|}
\hline \multirow[b]{2}{*}{ Item $^{2}$} & \multirow[b]{2}{*}{$\mathrm{CD}^{3}$} & \multicolumn{5}{|c|}{$\begin{array}{l}\text { Levels of substitution of basal diet used in digestibility } \\
\text { trials to estimate metabolizable energy of sticky coffee } \\
\text { hull }{ }^{1}(\%)\end{array}$} & \multirow[b]{2}{*}{ Mean } \\
\hline & & 7 & 14 & 21 & 28 & 15 & \\
\hline \multicolumn{8}{|c|}{ Growing } \\
\hline Initial weight, $\mathrm{kg}$ & 30.07 & 29.91 & 30.21 & 30.15 & 30.28 & 30.01 & - \\
\hline Final weight, $\mathrm{kg}$ & 60.30 & 58.04 & 59.93 & 62.03 & 58.01 & 61.70 & - \\
\hline Diet cost, $\mathrm{R} \$ / \mathrm{kg}$ & 0.58 & 0.65 & 0.65 & 0.66 & 0.68 & 0.66 & - \\
\hline ADI, R $\$ / k g$ LW gain & 1.44 & 1.61 & 1.64 & 1.61 & 1.69 & 1.64 & 1.60 \\
\hline EEI & 100.00 & 111.63 & 113.80 & 112.10 & 117.01 & 113.94 & - \\
\hline $\mathrm{CI}$ & 100.00 & 89.58 & 87.88 & 89.21 & 85.46 & 87.77 & - \\
\hline \multicolumn{8}{|c|}{ Finishing } \\
\hline Initial weight, $\mathrm{kg}$ & 60.00 & 59.94 & 59.86 & 59.96 & 59.99 & 60.40 & - \\
\hline Final weight, $\mathrm{kg}$ & 97.53 & 89.59 & 91.39 & 85.23 & 86.03 & 88.81 & - \\
\hline Diet cost, $\mathrm{R} \$ / \mathrm{kg}$ & 0.59 & 0.66 & 0.66 & 0.67 & 0.69 & 0.67 & - \\
\hline ADI, R $\$ / k g$ LW gain & $1.73 b$ & $2.08 \mathrm{a}$ & $2.08 \mathrm{a}$ & $2.27 \mathrm{a}$ & $2.13 \mathrm{a}$ & $2.09 \mathrm{a}$ & 2.05 \\
\hline EEI & 100.00 & 120.12 & 120.07 & 130.79 & 122.69 & 120.44 & - \\
\hline CI & 100.00 & 83.24 & 83.29 & 76.46 & 81.51 & 83.03 & - \\
\hline
\end{tabular}

${ }^{1}$ The values of metabolizable energy of sticky coffee hull $(\mathrm{SCH})$ used to calculate the diets were 2,456, 2,377, 2,247, 1,945 and 2,316 , respectively for $7,14,21,28$ e $15 \%$ of inclusion of SCH substituting basal diet. The level of $15 \%$ was estimated by regression. ${ }^{2} \mathrm{ADI}=$ Feed cost per $\mathrm{kg}$ of body weight, $\mathrm{EEI}=$ Economic Efficiency Index, Cost Index $(\mathrm{CI}) .{ }^{3} \mathrm{CD}=$ Control Diet.

\section{CONCLUSIONS}

The digestibility coefficients and performance results indicate that, for fibrous feedstuffs, higher levels of substitution of the basal diet by the test feedstuff result in an overestimated value of the fibrous ingredient. It is further concluded that the method of using increasing levels of substitution of the basal diet by the test feedstuff can be used as a tool to more precisely estimate the energy values of fibrous feedstuffs for pigs. The results suggest that for growing and finishing pigs, it can be used up to $28 \%$ and $15 \%$, respectively, of sticky coffee hull (fiber) without impairing performance and economic feasibility. For higher levels of inclusion (21\% and 28\%) there is a reduction on pig performance and increase the diets cost. 


\section{ACKNOWLEDGEMENTS}

The authors would like to thank COCAMAR for providing the sticky coffee hull and to CAPES and CNPq for Scholarships.

\section{REFERENCES}

ADEOLA, O. Digestion and balance techniques in pigs. In: LEWIS, A.J. and SOUTHERN, L.L. (Eds). Swine Nutrition. 2.ed., Washington: CRC Press, 2001. p.903-916.

ASSOCIAÇAO brasileira de criadores de suínos ABCS. Método Brasileiro de Classificação de Carcaças. Publicação Técnica n.2. Estrela/RS, 1973. $17 \mathrm{p}$.

BELLAVER, C.; FIALHO, E.T.; PROTAS, J.F.S. et al. Radícula de malte na alimentação de suínos em crescimento e terminação. Pesq. Agrop. Bras., v.20, p.969-974, 1985.

BRIDI, A.M.; SILVA, C.A. Métodos de avaliação da carcaça e da carne suína. Londrina: Midigraft, 2006. 97p.

CAMARA G.; SOUZA, R.C.M.; FREITAS, U.M. et al. Spring: Integrating remote sensing and GIS by object-oriented data modeling. Computers \& Graphics, v.20, p.395-403, 1996.

FERREIRA, E.R.A.; FIALHO E.T.; TEIXEIRA A.S. et al. Avaliação da composição química e determinação de valores energéticos e equação de predição de alguns alimentos para suínos. Rev. Bras. Zootec., v.26, p.514-523, 1997.

FIALHO, E.T., ROSTAGNO, H.S., FONSECA, J.B. et al. Efeito do peso vivo sobre o balanço energético e proteico de rações à base de milho e de sorgo com diferentes conteúdos de tanino para suínos. Rev. Bras. Zootec, v.8, p.386-397, 1979.

GOMES, M.F.M.; BARBOSA, H.P.; FIALHO, E.T. et al. Análise econômica da utilização de triguilho para suínos. Concórdia: EMBRAPACNPSA, p.1-2, 1991, (Comunicado Técnico, 179).

GOMES, J.D.F.; FUKUSHIMA, R.S.; PUTRINO, S.M. et al. Efeitos do incremento da fibra em detergente neutro na dieta de suínos sobre a morfologia dos órgãos digestivos e não digestivos. Braz. J. Vet. Res. Anim. Sci., v.43, p.210-219, 2006.

GOMES, J.D.F.; PUTRINO, S.M.; GROSSKLAUS, C. et al. Efeitos do incremento de fibra dietética sobre a digestibilidade, desempenho e características de carcaça: I. suínos em crescimento e terminação. Rev. Semina, v.28, p.483-492, 2007.

KEMPEN, V.T. Is fiber good for the pig? North Carolina Cooperative Extension Service. Swine News, v.24, p.1-2, 2001.

MATTERSON, L.D.; POTTER, L.M.; STUTZ, M.W. et al. The metabolizable energy of feed ingredients for chickens. Agri. Exp. Stat., Res. Report, v.7, p.11-14, 1965.

MOREIRA, I.; ROSTAGNO, H.S.; COELHO, D.T. et al. Determinação dos coeficientes de digestibilidade, valores energéticos e índices de controle de qualidade do milho e da soja integral processados pelo calor. Rev. Bras. Zootec., v.23, p.916-929, 1994.

NASCIMENTO, A.H.; GOMES, P.C.; ROSTAGNO, H.S. et al. Valores de Energia Metabolizável de Farinhas de Penas e de Vísceras Determinados com Diferentes Níveis de Inclusão e Duas Idades das Aves. Rev. Bras. Zootec., v.34, p.877-881, 2005 .

NUTRIENT requirements of swine. 10.ed. Washington: National Academic of Sciences, 1998. 189 p.

NOBLET, J.; PEREZ, J.M. Prediction of digestibility of nutrients and energy values of pigs diets from chemical analysis. J. Anim. Scie., v.71, p.3389-3398, 1993.

OLIVEIRA, S.L.; FIALHO, E.T.; MURGAS, L.D.S. et al. Utilização da casca de café melosa em rações de suínos em terminação. Cienc. $e$ Agrotecnol., v.26, p.1330-1337, 2002.

PEKAS, J.C. Versatile swine laboratory apparatus for physiologic and metabolic studies. J. Anim. Sci., v.27, p.1303-1309, 1968.

POND, W.G.; JUNG, H.G.; VAREL, V.H. Effect of dietary fiber on young adult genetically lean, obese, and contemporary pigs: body weight, carcass measurements, organ weights and digesta content. J. Anim. Scie., v.66, p.699-706, 1988.

POVEDA-PARRA, A.R.; MOREIRA, I.; FURLAN, A.C. et al. Utilização da casca de café na alimentação de suínos nas fases de crescimento e terminação. Rev. Bras. Zootec., v.37, p.433-442, 2008.

QUADROS, A.R.B.; MOREIRA, I.; PAIANO, D. et al. Avaliação nutricional da casca de soja integral ou moída, ensilada ou não, para suínos em fase de crescimento. Acta Scient. Anim. Scie., v.29, p.3138, 2007. 
ROSTAGNO, H.S.; ALBINO, L.F.T.; DONZELE, J.L. et al. Tabelas brasileiras para aves e suínos: composição de alimentos e exigências nutricionais. 2.ed. Viçosa: UFV, 2005. 186p.

SAKOMURA, N.K.; ROSTAGNO, H.S. Métodos de pesquisa em nutrição de monogástricos. Jaboticabal: Funep, 2007. 283p.

SILVA, D.J.; QUEIROZ, A.C. Análise de alimentos - métodos químicos e biológicos. 3.ed. Viçosa: Universidade Federal de Viçosa, 2002. 235p.

SISTEMA de análises estatísticas e genéticas SAEG. Versão 7.1. Viçosa: Universidade federal de viçosa - UFV, 1997. 150p.
ZANOTTO, D.L.; BELLAVER, C.N. Métodos de determinação da granulometria de ingredientes para o uso em rações de suínos e aves. Concórdia: CNPSA-EMBRAPA, 1996. p.15.

VILLAMIDE, M.J.; MAERTENS, L.; De BLAS, C.; et al. Feed Evaluation. In: De BLAS, C.; WISEMAN, J. (Eds.) The nutrition of the rabbit. UK: CAB Publishing, 1998. p.80-101.

VILLAMIDE, M.J. Methods of energy evaluation of feed ingredients for rabbits and their accuracy. Anim. Feed Scie. Technol., v.57, p.211-223, 1996. 